\title{
SELECTED ASPECTS OF DESIGN LIFESPAN OF FLEXIBLE PAVEMENT WITH ANTI-FATIGUE COURSE
}

\author{
M. NAGÓRSKA ${ }^{1}$, R. NAGÓRSKI ${ }^{2}$, K. BLAŻEJOWSKI ${ }^{3}$
}

\begin{abstract}
The aim of the study is to compare flexible pavement design lifespans and the main factors which create their values for a standard structure and one with an anti-fatigue course AF at different parameter values of pavement and its load, relevant to their design processes. Depending on the mixture used for the anti-fatigue course or the course thickness, durability improvement of the pavement (compared to the durability of a standard structure) can be obtained by extending the design lifespan of the asphalt base course or by extending the design lifespan of the AF course. On sections with predominantly slow traffic, the lifespan decreases significantly compared to sections with typical vehicle speed - the relative decrease is greater if anti-fatigue course is applied.
\end{abstract}

Keywords: flexible pavement, anti-fatigue course, design lifespan

\section{INTRODUCTION}

One way to reduce the fatigue and improve the durability of flexible pavement, is to add an additional anti-fatigue course (hereinafter referred to as AF course) to the three standard asphalt courses: wearing course, binder course and asphalt base course (see e.g. Nunn [1], Judycki, Jaskuła [2], Słotwiński [3], Sybilski at al. [4], Nagórski, Błażejowski, Marczuk [5]).

\footnotetext{
${ }^{1}$ Warsaw University of Technology, Faculty of Civil Engineering, Al. Armii Ludowej 16, 00-637 Warsaw, Poland, e-mail:m.nagorska@il.pw.edu.pl

${ }^{2}$ Warsaw University of Technology, Faculty of Civil Engineering, Al. Armii Ludowej 16, 00-637 Warsaw, Poland, e-mail: r.nagorski@il.pw.edu.pl

${ }^{3}$ ORLEN Asfalt, Płock, Poland,

e-mail: krzysztof.blazejowski@orlen.pl
} 
This course can be separated from the standard asphalt base course (by reducing the thickness of that course) or be an additional course which increases the final thickness of asphalt structure. It is assumed that the standard system of courses, by appropriately selecting the thickness of, in particular, binder course and asphalt base course and type of asphalt mixtures used in them, provides sufficient structural stiffness, and the wearing course also provides suitable functional characteristics of pavement surface.

Adding an additional, properly bonded, elastic, flexible, and consequently resistant to fatigue cracking AF course at the bottom of these courses can significantly increase the lifespan of the pavement (e.g. to provide at least a 50-year period of operation without 'deep repair', i.e. to obtain perpetual pavement, as referred to in the US). From an economic standpoint it is important to compensate for the addition of anti-fatigue course by reducing the thickness of other asphalt courses, specifically, the asphalt base.

The aim of this study is to compare the design lifespans and the main factors which create their values for the considered pavement variants (one standard and one with anti-fatigue AF course) at different pavement and its load parameters values, relevant to the process of flexible pavement dimensioning. It is assumed that fatigue cracking can occur in any asphalt course in which horizontal tensile strains may arise. Typically, such cracks can initiate at the bottom of the asphalt base course in a standard structure, and in a structure with AF course they may arise at both the bottom of that course or at the bottom of the asphalt base course situated above the AF course - depending on the relationship of stiffness and resistance to cracking of both layers.

An original element of the work is the analysis of a possible increase of the pavement's lifespan through replacing (in the standard system of asphalt courses) the lower part of the base course with anti-fatigue course - taking into account the possibility of fatigue cracks on the bottom of the asphalt base course or on the bottom of the anti-fatigue course:

- in conditions of heavy traffic and with typical or small motion speed,

- depending on the stiffness and cracking resistance of the anti-fatigue course in relation to the characteristics of the asphalt base course,

- comparatively for the two temperatures of the asphalt layers. 


\section{ASSUMPTIONS AND DATA}

For the purpose of analysis, two flexible structures were used: a standard one indicated by the symbol SS and a structure with an additional anti-fatigue asphalt course denoted by the symbol SS-AF, as shown in Fig. 1 and 2. The anti-fatigue course (AF) was added by reducing the thickness of the asphalt base course $(\mathrm{AB})$, with an unchanged total thickness of the two courses.

The SS structure and its various modifications (without altering the order of courses) was the subject of a mechanistic analysis under the research work of Nagórski, Błażejowski, Nagórska [6], the results of which were published in a monograph by Nagórski, Błażejowski, Nagórska [7]. This structure is similar to that provided in Regulation [8] for KR6 category of traffic.

For the basic structure of pavement with an anti-fatigue course, a thickness of $4 \mathrm{~cm}$ was assumed (the course indicated by AF4, and the structure by SS-AF4). For the selected case and the values of material and pavement load parameters, the thickness of the anti-fatigue course equal to $8 \mathrm{~cm}$ was assumed as a variant (with a corresponding reduction of thickness of the asphalt base course) - the course indicated by AF8, and the structure by SS-AF8. Such an AF course thickness was assumed, for example, on the experimental section Opacz - Paszków of the S8 expressway ${ }^{4}$.

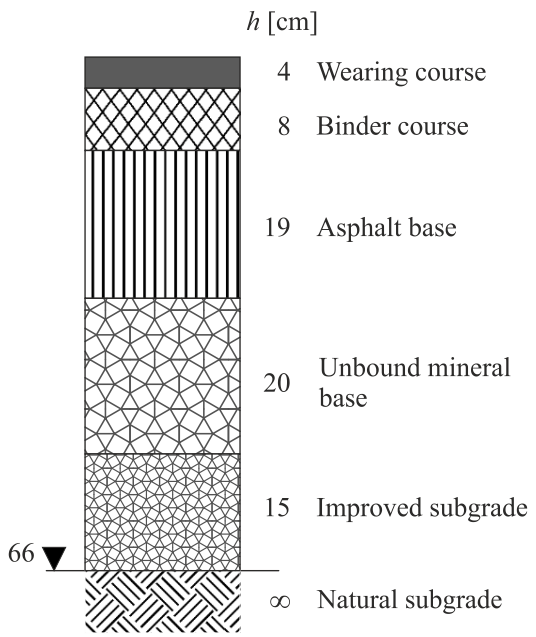

Fig. 1. Standard pavement structure: SS

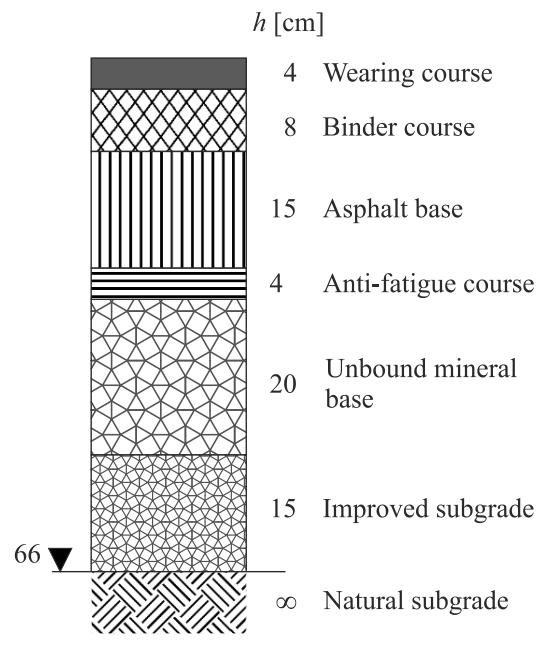

Fig. 2a. Basic pavement structure with an anti-fatigue course of $4 \mathrm{~cm}$ thick: SS-AF4

${ }^{4}$ According to GDDKiA and Strabag SE data 


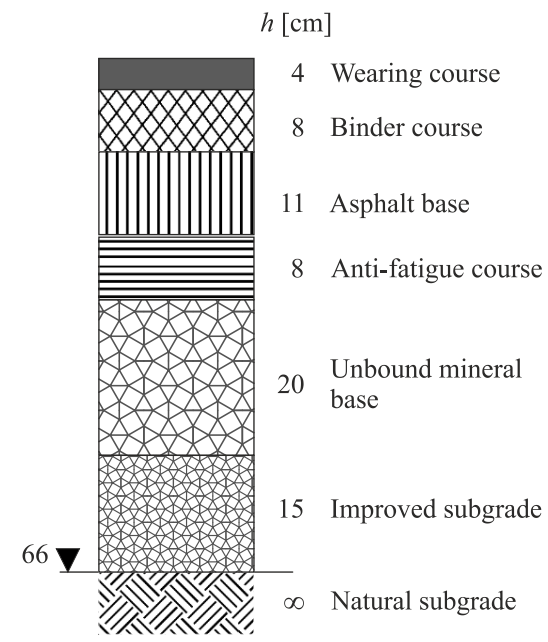

Fig. 2b. Pavement structure with an anti-fatigue course of $8 \mathrm{~cm}$ thick: SS-AF8

The typical pavement load was assumed (according to the Catalogues TNPP-2013 [9] and PRNPP2013 [10]) as a static vertical load of vehicle wheel $P=50 \mathrm{kN}$ (100 kN for the axis), distributed evenly over the circular surface with a radius of $a=0.1368 \mathrm{~m}$ at a pressure of $p=850 \mathrm{kN}$ (Fig. 3) and two vehicle speeds: typical for heavy traffic (indicated by HS) and low for slow traffic, e.g. at the approach to a crossroad (indicated by LS), which is reflected in the further adopted material parameters of asphalt courses.

a)

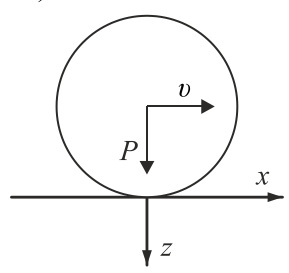

b)
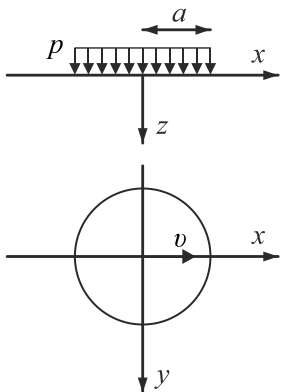

Fig. 3. Pavement loading scheme 
As a mechanical model of pavement an elastic layered half-space was assumed with homogeneous and isotropic layers of constant thickness, of Hooke material having parameters further compiled in the tables. The values of material parameters were assumed for the annual average temperature (so-called annual equivalent temperature) of $10^{\circ} \mathrm{C}$ according to the Regulation [8], which is also the average seasonal temperature for spring and autumn. In some load cases the values of material parameters of asphalt mixtures were assumed for the annual average temperature increased to $13^{\circ} \mathrm{C}$ according to Judycki et al. [11].

The material parameters of asphalt mixtures used in the standard courses of asphalt pavements SS and SS-AF: SMA 11 S PMB 45/80-55, AC 16 W MG 35/50, AC 22 P MG 35/50 (with multigrade bitumen MG or polymer modified bitumen PMB), from the collection of Technical Guidelines (WT) ZDW Katowice [12], have been determined based on the tests of samples in KOAC-NPC (the Netherlands) and included in the report Nagórski, Błażejowski, Nagórska [6]. Among other things, the measurements at $10^{\circ} \mathrm{C}$ of complex stiffness modulus $E^{*}(\omega)=S(\omega) \exp [\mathrm{i} \varphi(\omega)]$ have been done $(S$ $=\left|E^{*}\right|-$ dynamic stiffness modulus, $\varphi-$ phase shift angle, $\omega=2 \pi f-$ load cycle angular frequency in [rad], $f$ - cycle frequency in [Hz], i - imaginary unit), according to the Standard [13]. The values of parameters $S$ and $\varphi$ of the mentioned mixtures at $13^{\circ} \mathrm{C}$ were obtained using the possibility of the calculations of Huet-Sayegh model material parameters Pronk [14] of asphalt mixtures at different temperatures on the basis of parameter values determined in Nagórski, Błażejowski, Nagórska [6] (see also Nagórski, Błażejowski, Nagórska [7]).

As a basic option, the AF course used SMA 11 S PMB 45/80-55, i.e. an asphalt mixture which, due to the relatively high content of SBS-modified binder and small content of air voids, exhibits the desired feature of high tensile deformability and fatigue resistance. In order to show the different mechanisms of initiation of fatigue cracks, in a selected case of load the asphalt concrete mixture AC16 W 45/80-80 HiMA that was applied was comprised of highly-modified by SBS polymer binder ORBITON HiMA with a greater stiffness than the mixture SMA 11 S PMB 45/80-55. The ORBITON HiMA binder is also more resistant to cracking than typical PMB. On the other hand AC $22 \mathrm{P} \mathrm{MG}$ $35 / 50$ mixture used in the asphalt road base characterizes worse volumetric properties (lower binder content, higher amount of air voids) than the SMA mixture. This pavement option, with a thickness of $\mathrm{AF}$ asphalt course equal to $4 \mathrm{~cm}$, and which contains a highly-modified binder is designated with the symbol SS-AF4H.

The values of the modulus of elasticity (Young's modulus) $E$ of materials in asphalt courses were chosen to be equal to dynamic stiffness modulus $S_{f}$ of these materials at the annual average temperature at load frequency $f$ corresponding to the load speed appropriate to vehicle speed 
(Table 1 and 2). The frequency $f=10 \mathrm{~Hz}$ was assumed for traffic at typical speed and $f=1 \mathrm{~Hz}$ for low speed traffic (see Nagórski, Błażejowski, Nagórska [7]). The values of the modulus of elasticity of other courses (Table 3) and the values of Poisson's ratios of all courses were assumed in accordance with the Regulation [8] (Table 1-3). The values of Poisson's ratios of asphalt courses at $13^{\circ} \mathrm{C}$ were determined by interpolating the values of these ratios given in Regulation [8] for the temperature values equal to $-2^{\circ} \mathrm{C}, 10^{\circ} \mathrm{C}$ and $23^{\circ} \mathrm{C}$.

As shown in Nagórski, Nagórska, Błażejowski [15] (as well as in the monograph Nagórski, Błażejowski, Nagórska [7]), the use of the Hooke elastic model of pavement courses in question with the above values of the modulus of elasticity of asphalt courses leads to deflections and deformations, which determine pavement durability, that are substantially in line with the values of these quantities obtained using the Huet-Sayegh viscoelastic model of asphalt courses for the assumed pavement load with a speed of $60 \mathrm{~km} / \mathrm{h}$ as a typical speed of vehicles, and a speed of $5 \mathrm{~km} / \mathrm{h}$ as a slow traffic speed. Tables 1-3 show the values of material parameters of pavement courses in question.

The calculations of the components of displacement, strain and stress states were performed (using the VEROAD Program [16], [17]) for the SS and SS-AF4, SS-AF8 and SS-AF4H pavements, for the assumed mechanical course models and the values of their geometrical and material parameters, and for the pavement loading according to the Cartesian coordinates $x y z$ as in Fig. 3 ( $x=0$ means a fixed, but arbitrary cross-section of pavement, and the center of the surface of pavement load by vehicle wheel moves along the $x$-axis).

Table 1. The material parameters of SS and SS-AF asphalt courses for the Hooke elastic model with the values of elasticity modulus in two options for the temperature of these courses at $10^{\circ} \mathrm{C}$

\begin{tabular}{|c|l|c|c|c|}
\hline No. & \multicolumn{1}{|c|}{ Course type - material type } & $\begin{array}{c}\text { Poisson's ratio } \\
v[-]\end{array}$ & $\begin{array}{c}\text { Modulus of } \\
\text { elasticity } \\
E=S_{10 \mathrm{~Hz}} \\
{[\mathrm{MPa}]}\end{array}$ & $\begin{array}{c}\text { Modulus } \\
\text { of elasticity } \\
E=S_{1 \mathrm{~Hz}} \\
{[\mathrm{MPa}]}\end{array}$ \\
\hline 1 & Wearing course - SMA 11 S PMB 45/80-55 & 0.30 & 9837 & 5467 \\
\hline 2 & Binder course - AC 16 W MG 35/50 & 0.30 & 13818 & 10596 \\
\hline 3 & Asphalt base course - AC 22 P MG 35/50 & 0.30 & 12956 & 9561 \\
\hline $4 \mathrm{a}$ & AF4 and AF8 courses - SMA 11 S PMB 45/80-55 & 0.30 & 9837 & 5467 \\
\hline $4 \mathrm{~b}$ & AF4H course - AC 16 W PMB 45/80-80 HiMA & 0.30 & 11056 & not tested \\
\hline
\end{tabular}

$S_{10 \mathrm{~Hz}}-$ dynamic stiffness modulus at $f=10 \mathrm{~Hz}$ according to measurements

$S_{1 \mathrm{~Hz}}$ - dynamic stiffness modulus at $f=1 \mathrm{~Hz}$ according to measurements 
Table 2. The material parameters of SS and SS-AF asphalt courses for the Hooke elastic model with the values of elasticity modulus in two options for the temperature of these courses at $13^{\circ} \mathrm{C}$

\begin{tabular}{|c|l|c|c|c|}
\hline No. & \multicolumn{1}{|c|}{ Course type - material type } & $\begin{array}{c}\text { Poisson's ratio } \\
v[-]\end{array}$ & $\begin{array}{c}\text { Modulus of } \\
\text { elasticity } \\
E=S_{10 \mathrm{~Hz}} \\
{[\mathrm{MPa}]}\end{array}$ & $\begin{array}{c}\text { Modulus of } \\
\text { elasticity } \\
E=S_{1 \mathrm{~Hz}} \\
{[\mathrm{MPa}]}\end{array}$ \\
\hline 1 & Wearing course - SMA 11 S PMB 45/80-55 & 0.33 & 8286 & 3924 \\
\hline 2 & Binder course - AC 16 W MG 35/50 & 0.33 & 12721 & 9141 \\
\hline 3 & Asphalt base course - AC 22 P MG 35/50 & 0.33 & 11828 & 8157 \\
\hline $4 \mathrm{a}$ & AF4 and AF8 courses - SMA 11 S PMB 45/80-55 & 0.33 & 8286 & 3924 \\
\hline
\end{tabular}

$S_{10 \mathrm{~Hz}}$ - dynamic stiffness modulus at $f=10 \mathrm{~Hz}$ based on calculations according to the Huet-Sayegh model $S_{1 \mathrm{~Hz}}$ - dynamic stiffness modulus at $f=1 \mathrm{~Hz}$ based on calculations according to the Huet-Sayegh model

Table 3. The material parameters of SS and SS-AF non-asphalt courses for the Hooke elastic model

\begin{tabular}{|c|l|c|c|}
\hline No. & \multicolumn{1}{|c|}{ Course type - material type } & $\begin{array}{c}\text { Poisson's ratio } \\
v[-]\end{array}$ & $\begin{array}{c}\text { Modulus of elasticity } \\
E[\mathrm{MPa}]\end{array}$ \\
\hline 1 & Unbound base - compacted mineral aggregate & 0.30 & 400 \\
\hline 2 & $\begin{array}{l}\text { Improved subgrade - cement-treated soil } \\
R_{\mathrm{m}}=2.5 \mathrm{MPa}\end{array}$ & 0.30 & 300 \\
\hline 3 & Subgrade - G1 soil & 0.35 & 100 \\
\hline
\end{tabular}

Given the designation of asphalt courses for the comparative analysis of design lifespan in respect of fatigue cracking, and the subgrade (at a cyclic load) in respect of vertical rutting, the presentation of calculated results focused on the maximum values of critical deformations, i.e.:

a) maximum values $\varepsilon_{\mathrm{a}}$ of strains $\varepsilon_{x x}$ and $\varepsilon_{y y}$ at the bottoms of asphalt courses where tensile occurs, determining the design lifespan in respect of fatigue cracking (wherein $\varepsilon_{\mathrm{a}}=\varepsilon_{y y}$ for the load in question),

b) maximum values $\varepsilon_{\mathrm{s}}$ of deformations $\varepsilon_{z z}$ on the surface of the subgrade, determining the design lifespan in respect of permanent subgrade deformation.

The fatigue life of the pavement in respect of fatigue cracking was calculated from the Asphalt Institute formulas Piłat, Radziszewski [18]:

$$
\begin{gathered}
N_{\mathrm{f}}=N_{\mathrm{ph}} N_{\mathrm{m}}, \quad N_{\mathrm{ph}}=18.4 \cdot 10^{M}, \quad M=4.84\left(\frac{V_{\mathrm{a}}}{V_{\mathrm{a}}+V_{\mathrm{v}}}-0,69\right), \\
N_{\mathrm{m}}=6.167 \cdot 10^{-5} \cdot \varepsilon_{\mathrm{a}}^{-3,291} \cdot S_{\mathrm{a}}^{-0,854},
\end{gathered}
$$


where:

$N_{\mathrm{f}}$ - calculated fatigue life (in [number of standard axles]),

$S_{\mathrm{a}}-$ stiffness modulus of asphalt course [MPa],

$\varepsilon_{\mathrm{a}}-$ maximum tensile strain (horizontal) at the bottom of the asphalt course [1],

$N_{\mathrm{m}}$ - mechanical factor of calculated lifespan,

$V_{\mathrm{a}}$ - volume content of binder in the mixture of asphalt course [\% v/v],

$V_{\mathrm{v}}$ - volume content of air voids in the mixture of asphalt course $[\% \mathrm{v} / \mathrm{v}]$,

$N_{\text {ph }}$ - physical factor of calculated lifespan.

In the Eq. (2.1) one can use the parameters of asphalt courses in which, due to horizontal tensile strains, fatigue cracks may initiate.

Table 4 summarizes the values of volumetric parameters of mixtures used in the lowest courses of asphalt, established in Nagórski, Błażejowski, Nagórska [6].

Table 4. Material (physical) parameters of mineral-asphalt mixtures

\begin{tabular}{|c|c|c|c|}
\hline No. & $\begin{array}{c}\text { Type }- \text { identification } \\
\text { of mixture }\end{array}$ & $\begin{array}{c}\text { Asphalt content } V_{\mathrm{a}} \\
{[\% \mathrm{v} / \mathrm{v}]}\end{array}$ & $\begin{array}{c}\text { Voids } V_{\mathrm{v}} \\
{[\% \mathrm{v} / \mathrm{v}]}\end{array}$ \\
\hline 1 & SMA 11 S PMB 45/80-55 & 15.4 & 3.0 \\
\hline 2 & AC 22 P MG 35/50 & 11.1 & 4.6 \\
\hline 3 & AC 16 W PMB 45/80-80 HiMA & 11.1 & 4.1 \\
\hline
\end{tabular}

It is generally assumed that the fatigue cracks may occur at the bottom of the lowest asphalt course in the standard structure and in the structure with an anti-fatigue course at the bottom of the lowest (i.e. anti-fatigue) course or at the bottom of the next asphalt course (i.e. asphalt road base) - depending on the relationship of stiffness and the resistance to the cracking of the two courses (Fig. 4).

As stiffness modulus $S_{\mathrm{a}}$ in Eq. (2.1) the dynamic modulus of the mixture in asphalt course $S_{f}$ was adopted, respectively at $f=1 \mathrm{~Hz}$ for low speed (LS) and $f=10 \mathrm{~Hz}$ for typical speed (HS) of the load. 


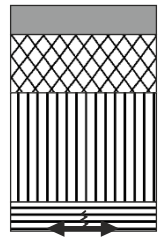

Wearing course

Binder course

Asphalt base course

Anti-fatigue course

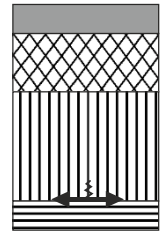

Fig. 4. Schemes of fatigue crack initiation in pavement structure with anti-fatigue course

The pavement lifespan in respect of permanent subgrade deformation under the cyclic load of pavement is calculated according to the following formula Piłat, Radziszewski [18]:

$$
N_{\mathrm{d}}=\left(\frac{k}{\varepsilon_{\mathrm{s}}}\right)^{1 / m},
$$

where:

$N_{\mathrm{d}}$ - calculated lifespan (in [number of standard axles]),

$k=1.05 \cdot 10^{-2}, m=0.223$,

$\varepsilon_{\mathrm{s}}-$ maximum vertical compressive strain $\varepsilon_{z z}$ on the upper surface of the subgrade (in the Eq. (2.2)

we substitute the absolute value of $\varepsilon_{\mathrm{s}}$ ).

The above specified values of $N_{\mathrm{f}}$ i $N_{\mathrm{d}}$ were determined for a given annual average temperature of asphalt courses, and thus for the values of parameters and material factors suitable for that temperature.

\section{Calculation Results}

Table 5 contains a comparison of the values of calculated lifespans $N_{\mathrm{f}}$ i $N_{\mathrm{d}}$, as well as the values of critical strains $\varepsilon_{\mathrm{a}}$ and $\varepsilon_{\mathrm{s}}$ and stiffness modulus $S_{\mathrm{a}}$ occurring in Eq. (2.1) and Eq. (2.2) and, moreover, in the case of lifespan in respect of fatigue cracking $N_{\mathrm{f}}$, of the quantities $N_{\mathrm{ph}}, N_{\mathrm{m}}$. The strains $\varepsilon_{\mathrm{a}}$ and $\varepsilon_{\mathrm{s}}$ can be used when applying any method or formula when determining the pavement lifespan, other than the formulas of the Asphalt Institute. In contrast, the quantities $N_{\mathrm{ph}}$ i $N_{\mathrm{m}}$ show the effects that physical and mechanical factors have on fatigue initiation. It may be that a slight increase in the critical strain which results from the change in the course mixture is accompanied by increased lifespan, because, despite the reduction in $N_{\mathrm{m}}, N_{\mathrm{ph}}$ increases more. 


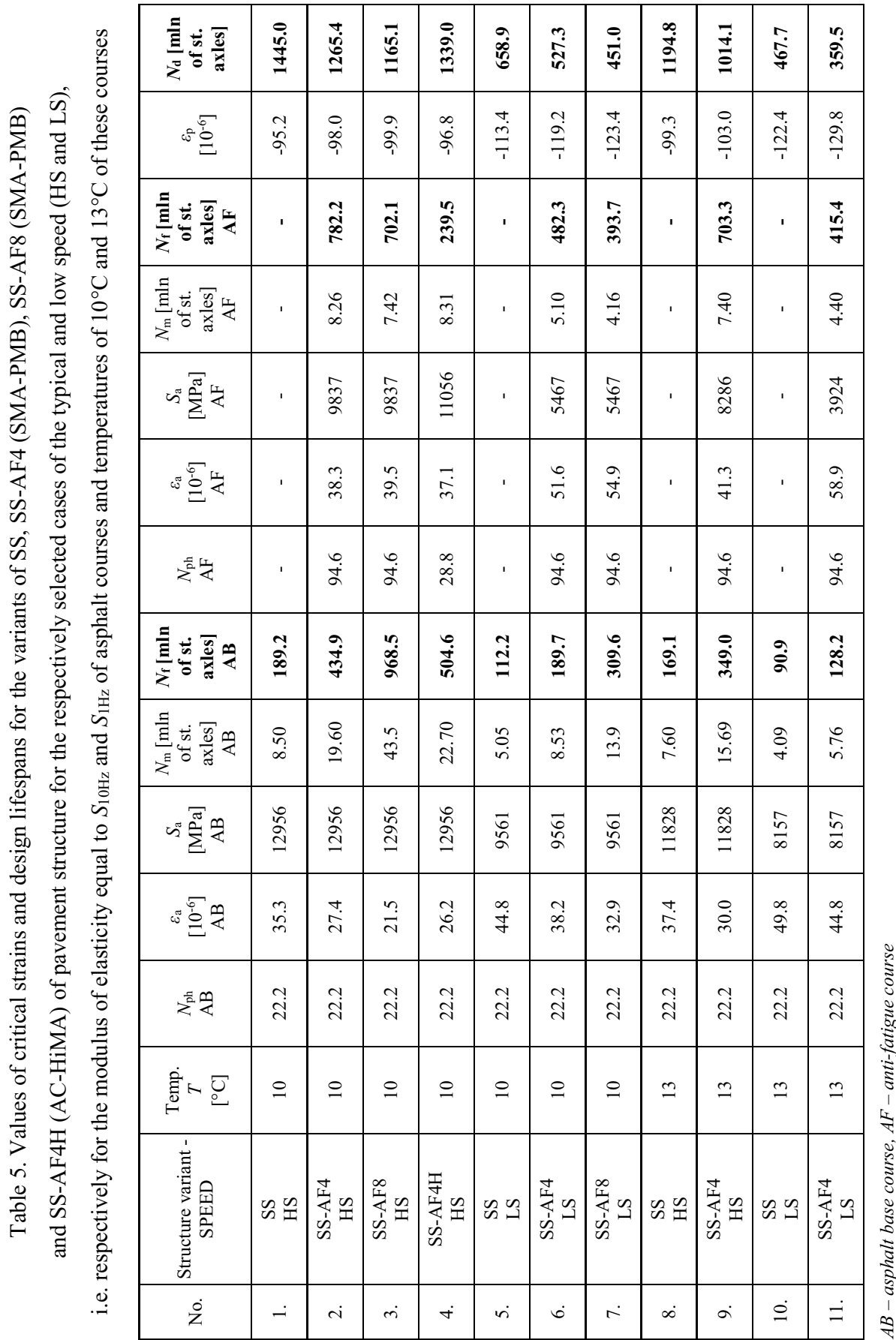




\section{RESULTS ANALYSIS}

From the results of the calculations presented in Table 5 the following observations arise:

1. The lifespan of pavement, in both the standard pavement structure (SS), as well as the structure with anti-fatigue course (SS-AF), is determined in each of the considered variants and data cases by a lifespan in respect of fatigue cracking $N_{\mathrm{f}}$. The lifespan in respect of structural deformation $N_{\mathrm{d}}$ is definitely higher.

2. The use of an anti-fatigue course $\mathrm{AF}$ at the bottom of the system of asphalt courses, with a cor-responding reduction of thickness of the asphalt base course $\mathrm{AB}$ increases the design fatigue lifespan of SS-AF4 and SS-AF8 pavements (according to Asphalt Institute formulas) when compared to standard SS pavement. An AF course reduces the pavement design lifespan in respect of structural deformation, but this is not a relevant reduction since the criterion in respect of fatigue cracking is still decisive.

3. The application of an AF course with poorer stiffness than the asphalt concrete of the base course in each analysed case increased the volume of critical tensile strains (fatigue strains), in extreme cases by $12 \%$. This increase rises with decreasing stiffness of the AF course compared to the stiffness of the classical asphalt base course, and with growing thickness of the AF course. This is understandable because lower stiffness of the AF course weakens the stiffness of the entire system of asphalt courses, which has the consequence of greater deflection and strains the whole structure.

4. Despite an increase in the critical tensile strain at the bottom of the asphalt courses system, the use of an AF course resulted in an increase of the fatigue life of the whole structure, which is due to better properties (from the perspective of fatigue strength) of the asphalt mixtures used in the AF course.

5. The significantly higher fatigue life $N_{\mathrm{f}}$ of an $\mathrm{AF}$ course (despite an increase in the critical strain $\varepsilon_{\mathrm{a}}$ ) is due to the value of physical factor $N_{\mathrm{ph}}=94.6$ which is more than four times higher than its value $N_{\mathrm{ph}}=22.2$ for the asphalt base course of AC 22 P MG. This factor is correlated with a significant deformability of SMA 11 S PMB mixture - stretching capacity - implying a high resistance to fatigue cracking, and with substantially different properties of the two mixtures, particularly in terms of the content of binder and air voids.

6. In the case of structures SS-AF4 and SS-AF8, in which an AF course mixture SMA 11 S PMB was used, a significant increase in the pavement lifespan is achieved through 
the increase in fatigue life of the asphalt base course AB. It should be noted that the fatigue life of the asphalt base course is also much shorter than the fatigue life $N_{\mathrm{f}}$ of an AF course, and also shorter in lifespan in terms of structural resistance to permanent deformation $N_{\mathrm{d}}$.

7. Since critical deformations of the AF course, i.e. at the bottom of the asphalt base course AB, are smaller than in the SS structure, the result is an increase in the design lifespan of a structure with an AF course in respect of fatigue cracking compared to the lifespan of a standard structure. By describing this mechanism differently, we can conclude that fatigue resistant AF course adopts the largest critical strain, so that deformation in the asphalt base course located above the AF layer is reduced to a safe level for this classic mixture. It is a synthetic confirmation of the idea of perpetual pavement with an anti-fatigue course.

8. In the case of a SS-AF4 structure (at $10^{\circ} \mathrm{C}$ ), the fatigue life of the AF course is 782.2 million axles, while the lifespan of the asphalt base course $\mathrm{AB}$ is 434.9 million axles, which means that the asphalt base course will be destroyed first.

9. In the case of a SS-AF8 structure $\left(\right.$ at $\left.10^{\circ} \mathrm{C}\right)$ with the $\mathrm{AF}$ course thickness increased up to $8 \mathrm{~cm}$ (and the thickness of the asphalt base course reduced by $8 \mathrm{~cm}$ ) we obtain, in comparison with the structure of SS-AF4, a reduction in stiffness of pavement courses and, consequently, an increase in critical strains $\varepsilon_{\mathrm{a}}$ in $\mathrm{AF}$ course and a decrease in critical strains $\varepsilon_{\mathrm{a}}$ in the asphalt base course $\mathrm{AB}$ (as the bottom of the layer is much closer to the surface of zero strain). As a result, the fatigue performance of the $\mathrm{AB}$ course increases from 434.9 million to 968.5 million axles and the fatigue performance of the AF course decreases from 782.2 million to 702.1 million axles in the case of traffic at a speed of $60 \mathrm{~km} / \mathrm{h}$, and the fatigue performance of the $\mathrm{AB}$ course increases from 189.7 million axles to 309.6 million axles whereas the fatigue performance of the AF course decreases from 482.3 million axles to 393.7 million axles in the case of traffic at a speed of $5 \mathrm{~km} / \mathrm{h}$. Thus, in the case of a load with a typical speed, the improved effective lifespan of SS-AF8 pavement structure (compared with the lifespan of SSAF4 structure) is determined by the fatigue performance of the AF course (the increase in pavement lifespan is 1.6-fold), and, in the case of slow traffic, it is determined by the fatigue performance of the $\mathrm{AB}$ course (the increase in lifespan is only 1.2-fold). The lifespan in respect of subgrade deformation remains significantly higher than the lifespan in respect of fatigue cracking. 
10. In the SS and SS-AF4 structures (at the temperature of asphalt courses of $10^{\circ} \mathrm{C}$ ), for a typical load speed, the improvement of $N_{\mathrm{f}}$ due to AF course (if compared with $N_{\mathrm{f}}$ without that course) is 2.3 -fold and at a low speed is 1.7 -fold.

11. For the asphalt courses at a temperature of $13^{\circ} \mathrm{C}$ we can observe the decrease in pavement lifespan, in relation to the lifespan at a temperature of $10^{\circ} \mathrm{C}$, by $10.6 \%$ (SS, HS), $19.8 \%$ (SS-AF4, HS), $19.0 \%$ (SS, LS) and 32.4\% (SS-AF4, LS) respectively. At the same time, for a typical load speed the improvement of $N_{\mathrm{f}}$ due to AF course (if compared with $N_{\mathrm{f}}$ without that course) is 2.1-fold and at low speed only 1.4 -fold.

12. Where the mixture AC $16 \mathrm{~W}$ PMB HiMA was used for the anti-fatigue course AF in the SSAF4 structure, an increase in pavement lifespan compared to the lifespan of the standard pavement is achieved thanks to the increase in the fatigue life of the AF course, which in relation to the SMA $11 \mathrm{~S}$ PMB mixture, has a greater stiffness. However, the strain at the bottom of the AF course in the SS-AF structure is higher by $5 \%$ from the strain at the bottom of the lower asphalt course in the SS structure because the stiffness of the mixture AC 16 HIMA is lower than that of mixture AC $22 \mathrm{P} \mathrm{MG}$, but the increase in value of $22 \mathrm{~N}_{\mathrm{ph}}$ from 22.2 to 28.8 results in nearly a 1.3-fold increase in fatigue life $N_{\mathrm{f}}$ of AF course in relation to the lifespan of the base course in the SS structure. Thus, an increase in lifespan of pavement is not as high as with SMA $11 \mathrm{~S}$ PMB used as an AF course in the discussed case. For example, at the typical load speed for the temperature of $10^{\circ} \mathrm{C}$ of asphalt courses, this increase was 2.3 -fold. The results obtained are undoubtedly influenced by volumetric parameters of the AC $16 \mathrm{~W}$ mixture which, compared to the SMA $11 \mathrm{~S}$ mixture, has a lower volume content of binder and higher content of air voids and is therefore a priori less fatigue resistant according to the empirical Eq. (2.1) of the Asphalt Institute. The specified differences directly affect the $N_{\text {ph }}$ parameter value and the achieved design lifespans. Since the HiMA type binders are characterized by significantly better fatigue strength than the PMB 45/80-55 binder, which is used in the SMA of SS-AF4 and SS-AF8 courses, we can conclude that the Eq. (2.1) in the case of non-conventional binders generate results which are not fully reliable. However, these formulas can be used for comparison to the same asphalt mixtures in different variants of pavement structure and cases of its loading.

13. The effectiveness of an anti-fatigue course is highest when using the right asphalt mixture type. It should be a mixture with a high volume content of binder and low content of air voids simultaneously with sufficiently high stiffness. In addition, the impact of binder on the values of stiffness modulus obtained must be considered in such a way that significant 
differences between the stiffness of the asphalt base course $\mathrm{AB}$ and the stiffness of the $\mathrm{AF}$ course resulting in formation of fatigue cracks in the base course can be avoided.

14. The anti-fatigue course may be used as a way to compensate for the reduced lifespan for slow traffic in relation to the lifespan for typical speed traffic. Full compensation (in numbers) for AF4 is obtained at a temperature of $10^{\circ} \mathrm{C}$ of asphalt courses. In contrast, for a temperature of $13^{\circ} \mathrm{C}$ the thickness of the asphalt base course or the thickness of the anti-fatigue course should be additionally increased.

\section{CONCLuSions}

Summing up the results of the calculations presented and their analysis, the following can be stated:

1. Depending on the asphalt mixture type used for the anti-fatigue course and the thickness of this course, an improvement of the lifespan of the entire pavement when compared to the lifespan of a standard structure can be obtained by increasing the lifespan of the asphalt base course (with a significantly greater increase in lifespan of the anti-fatigue course) or by increasing the lifespan of the anti-fatigue course (with a greater increase in lifespan of the asphalt base course). It is therefore necessary to determine which of these lifespans is lower as it is crucial for the lifespan in respect of fatigue cracking of the whole pavement structure.

2. The asphalt mixture which is used in an anti-fatigue course should have specified physical (e.g. volumetric binder content, air voids content) and mechanical properties (tensile and fatigue resistance, stiffness modulus etc.). Except high tensile resistance, the stiffness of the course should be designed with care because it cannot be too low in relation to the stiffness of the asphalt layer situated above. The anti-fatigue course should also fulfill a structural function, ensuring sufficient stiffness of the entire structure (and small tensile strains as an effect). The described behaviour is especially important when the temperature of the asphalt courses increases and their stiffness decreases. If an AF course has too little stiffness than required for the structure, the asphalt base (course above AF) will crack first. Besides this, in structures with such an AF course, an increase of asphalt base lifespan is only minimal because the tensile strain at the bottom of this course does not decrease enough compared to a standard structure. In order to avoid this phenomenon, apart from application of stiffer mixtures, the thickness of the AF course could be increased. Obviously the final pavement will be more expensive in this case. 
3. On sections with predominantly or significantly slow traffic, the lifespan of pavement, when compared to the lifespan of sections with a typical vehicle speed, decreases significantly relatively more if an anti-fatigue course was used than without it. The use of an anti-fatigue course in order to increase the lifespan of pavement in areas of slow traffic, as in areas with typical speed, may not be satisfactory. Then one should increase the thickness of the AF course or increase the thickness of the asphalt base course, remembering that the total cost of pavement will increase in this case.

\section{REFERENCES}

1. M. E. Nunn, Design of Long-Life Roads for Heavy Traffic, Australian Asphalt Pavement Association Industry Conference 1998, Surfers Paradise, Queensland, Australia and M.E. Nunn, A. Brown, D. Weston, J. C. Nicholls, Design of Long-Life Roads for Heavy Traffic, TRL Report 250, 1997

2. J. Judycki, P. Jaskuła, Nowoczesne nawierzchnie asfaltowe (Modern asphalt pavements), Politechnika Gdańska, Katedra Inżynierii Drogowej, Gdańsk, X 2008

3. D. Słotwiński, Nowe koncepcje konstrukcji nawierzchni asfaltowych (The new ideas of asphalt pavement structures). Drogownictwo, No. 7, 8 (2002), 218-223

4. D. Sybilski et al., Nawierzchnie asfaltowe długowieczne i tanie w utrzymaniu (Long-life and low-cost maintenance asphalt pavements), Raport z pracy badawczej na zlecenie GDDKiA, Instytut Badawczy Dróg I Mostów. Warszawa, 2009 - part 1,2010 - part 2, 2011 - part 3, 2012 - part 4, part 5

5. R. Nagórski, K. Błażejowski, K. Marczuk, Comparative analysis of strains and durability of asphalt pavement of perpetual and standard type / Analiza porównawcza odkształceń oraz trwałości nawierzchni asfaltowej typu „perpetual” i nawierzchni standardowej, Roads and Bridges — Drogi i Mosty, 11 (2012), pp. 311-327

6. R. Nagórski, K. Błażejowski, M. Nagórska, Badania mieszanek mineralno-asfaltowych i analiza konstrukcji nawierzchni podatnych $\mathrm{z}$ uwzględnieniem trwałości nawierzchni (The tests of asphalt mixtures and flexible pavement structures analysis including their lifespan), Report on implementation of research project ordered by Voivodeship Roads Authority in Katowice and SKN Sp. z o.o., Faculty of Civil Engineering, Warsaw University of Technology, Warsaw 2013

7. R. Nagórski, K. Błażejowski, M. Nagórska, Studium właściwości mechanicznych konstrukcji nawierzchni drogowej podatnej z uwzględnieniem trwałości. Zagadnienia wybrane (The study of mechanical properties of the road flexible pavement structure includiingits durability. Selected topics), Studies on Engineering Series, no. 87, Committee for Civil and Water Engineering of Polish Academy of Sciences, Warsaw 2014, p. 141

8. Rozporządzenie Ministra Transportu i Gospodarki Morskiej z dnia 2 marca 1999 r. w sprawie warunków technicznych, jakim powinny odpowiadać drogi publiczne i ich usytuowanie. Załącznik 5. Projektowanie konstrukcji nawierzchni dróg (The Regulation on technical requirements for public roads and their location. Appendix 5 - Dimensioning of pavements' structures), Journal of Polish Law No. 43, item. 430, Warsaw 1999.

9. Katalog typowych konstrukcji nawierzchni podatnych i półsztywnych (The Catalogue of typical flexible and semi-rigid pavements' structures), General Directorate for National Roads and Motorways and Department of Road Engineering of Technical University of Gdańsk, Gdańsk 2013

10. Katalog przebudów i remontów nawierzchni podatnych i półsztywnych (The Catalogue of re-buildings and repairs of flexible and semi-rigid pavements), General Directorate for National Roads and Motorways and Road and Bridge Research Institute, Warsaw 2013

11. J. Judycki et al. Analiza i projektowanie nawierzchni podatnych i półsztywnych (An analysis and designing of flexible and semi-rigid pavements), collective work, edited by J. Judycki. Wydawnictwa Komunikacji I Łączności, 2014

12. Wytyczne Techniczne: WT SMA 11 S. WT AC 16 W. WT AC 22 P ZDW w Katowicach (Technical Guidelines for asphalt mixtures SMA11S, AC16W, AC22P published by Silesian Voivodeship Roads Authority in Katowice), Katowice 2013

13. PN-EN 12697-26: Mieszanki mineralno-asfaltowe-Metody badań mieszanek mineralno-asfaltowych na gorąco - Część 26: Sztywność (Asphalt mixtures - Methods of test - Part 26: Stiffness)

14. A.C. Pronk, Revival of the Huet-Sayegh Response Model, DWW-2003-29, RHED, Delft 2003. 
15. R. Nagórski, M. Nagórska, K. Błażejowski, Model sprężysty w projektowaniu nawierzchni drogowej podatnej a właściwości lepkosprężyste warstw asfaltowych (The elastic model in designing of flexible pavement and viscoelastic properties of asphalt layers), Logistyka, 3/2014, 4540-4553

16. P.C. Hopman, The Visco-Elastic Multilayer Program VEROAD. Heron, Vol. 41, 1996, No 1

17. VEROAD. User Manual, KOAC-NPC, v. 2000, Utrecht 2001

18. J. Piłat, P. Radziszewski, Nawierzchnie asfaltowe (Asphalt pavements), WKŁ, 2nd edition, Warsaw 2007 